\title{
Genetic Variation in Ustilago Bullata: Molecular Genetic Markers and Virulence on Bromus Tectorum Host Lines
}

\author{
Mikel Stevens \\ mikel_stevens@byu.edu \\ Daniel J. Fairbanks \\ Susan E. Meyer \\ David L. Nelson \\ Suzette Clement
}

See next page for additional authors

Follow this and additional works at: https://scholarsarchive.byu.edu/facpub

Part of the Animal Sciences Commons, and the Plant Sciences Commons

\section{Original Publication Citation}

International Journal of Plant Sciences 166.1(Jan 25): 15-115.

\section{BYU ScholarsArchive Citation}

Stevens, Mikel; Fairbanks, Daniel J.; Meyer, Susan E.; Nelson, David L.; Clement, Suzette; and Waters, Jennifer, "Genetic Variation in Ustilago Bullata: Molecular Genetic Markers and Virulence on Bromus Tectorum Host Lines" (2005). Faculty Publications. 994.

https://scholarsarchive.byu.edu/facpub/994

This Peer-Reviewed Article is brought to you for free and open access by BYU ScholarsArchive. It has been accepted for inclusion in Faculty Publications by an authorized administrator of BYU ScholarsArchive. For more information, please contact ellen_amatangelo@byu.edu. 


\section{Authors}

Mikel Stevens, Daniel J. Fairbanks, Susan E. Meyer, David L. Nelson, Suzette Clement, and Jennifer Waters 
Int. J. Plant. Sci. 166(1):105-115. 2005.

Copyright is not claimed for this article.

\title{
GENETIC VARIATION IN USTILAGO BULLATA: MOLECULAR GENETIC MARKERS AND VIRULENCE ON BROMUS TECTORUM HOST LINES
}

\author{
Susan E. Meyer, ${ }^{1, *}$ David L. Nelson,* Suzette Clement,* Jennifer Waters, $†$ Mikel Stevens, $†$ and Daniel Fairbanks $†$ \\ *USDA Forest Service, Rocky Mountain Research Station, Shrub Sciences Laboratory, 735 North 500 East, Provo, Utah 84606, U.S.A.; \\ and tDepartment of Plant and Animal Science, Brigham Young University, Provo, Utah 84602, U.S.A.
}

\begin{abstract}
The pathogen Ustilago bullata often causes epidemic levels of head smut disease in Intermountain populations of the inbreeding annual grass Bromus tectorum. We examined patterns of genetic variation for virulence and for amplified fragment length polymorphism (AFLP) markers in four U. bullata populations on B. tectorum in northern Utah and southern Nevada. Patterns of disease incidence generally supported a genefor-gene model for virulence and resistance in this pathosystem. Most host lines were susceptible to most or all paired isolates included in cross-inoculation tests, but we found evidence for the existence of four avirulence genes. Host lines with alleles conferring resistance were usually resistant to races not found in co-occurring pathogen populations. The exception was the population at Potosi Pass, Nevada, where the prevalent host line possessed an allele conferring resistance to one of two co-occurring races. The two pathogen races at Potosi Pass were also strongly genetically differentiated in terms of their AFLP genotypes, whereas for the other three populations, there was no relationship between virulence phenotype and AFLP genotype. There was little evidence for high levels of inbreeding in the northern pathogen populations, which showed no clear groupings of isolates within or among populations. The correlation of the virulence phenotype with the AFLP genotype at Potosi Pass was associated with the presence of a mating locus-linked haplolethal trait in the race pathogenic on the prevalent host line. The presence of this trait is coincident with a high level of intratetrad selfing in this race, thus isolating it from the co-occurring race and leading to fixation of most AFLP markers. The Potosi Pass population was also clearly differentiated from the northern populations, which were genetically similar to each other, a pattern also seen in the co-occurring host populations, providing evidence for the idea of pathogen dispersal through seedborne inoculum.
\end{abstract}

Keywords: AFLP, cheatgrass, downy brome, haplolethal, head smut, pathogenicity, resistance.

\section{Introduction}

Ustilago bullata Berk., the causal organism for head smut disease of grasses, has one of the widest known host ranges of any smut pathogen, with the ability to infect species in at least seven genera (Fischer and Holton 1957). The wide host range of $U$. bullata is attributable to its differentiation into numerous races that are pathogenic on specific subsets of hosts (Fischer 1940a; Meiners and Fischer 1953). This race specialization is known to apply not only at the level of species but within host species as well. Kreizinger et al. (1947) showed that races that had been defined on the basis of differentials at the species level were complex genetic entities that could be further subdivided based on their ability to infect particular genotypes within host species.

Among the species most often afflicted with head smut disease at epiphytotic levels are weedy annual species of the genus Bromus. We have presented evidence showing that Bromus tectorum L. (cheatgrass, downy brome) exhibits race-specific resistance to $U$. bullata in Intermountain Western North America (Meyer et al. 2001). But it is not clear

1 Author for correspondence; telephone 801-356-5125; fax 801375-6968; e-mail smeyer@fs.fed.us.

Manuscript received November 2003; revised manuscript received June 2004. what role this resistance plays in the population biology of the host or in its interaction with the pathogen.

Bromus tectorum is a self-pollinating species whose populations can be thought of as assemblages of finite numbers of inbreeding lines (McKone 1985; Ramakrishnan et al. 2004). Such populations show relatively low genetic diversity in terms of isozymes (Novak and Mack 2001) and DNA-based molecular markers (Ramakrishnan 2002). Phenotypic plasticity accounts for much of the variation in plant size and reproductive output observed under field conditions (Rice and Mack 1991). But adaptively significant genetic variation (Rice and Mack 1991; Meyer and Allen 1999; Meyer et al. 2004) also plays an important role in the remarkable success of this exotic species, which currently dominates more than 40 million ha in the Intermountain region (Whisenant 1990). Genetic variation in resistance to the head smut pathogen may be a significant component of this success.

Ustilago bullata is a seedling-infecting pathogen that grows systemically in the heterokaryotic phase, then sporulates in the host inflorescence, producing masses of diploid teliospores (Fischer and Holton 1957). The teliospores disperse, germinate, and undergo meiosis to produce four haploid cells, usually in a linear tetrad within a promycelium. Normally each of these haploid cells is capable of either fusion with a cell of opposite mating type or saprophytic budding 
to produce yeastlike haploid sporidial cells. This haploid phase may be more or less extended and functions to increase the probability of successful infection by multiplying the number of cells capable of forming infective units. Fusion of cells of opposite mating type is necessary for the production of the dikaryotic infection hypha that penetrates the seedling and initiates systemic mycelial growth. Sporulation by the pathogen usually eliminates seed production. This effectively terminates the life cycle of the host in annual grasses, which rely entirely upon seeds for the production of a new generation. Infection with head smut may also cause mortality in host seedlings and could affect competitive ability, because infected individuals tend to be dwarfed (D. L. Nelson, personal observation).

In this study, we sought to characterize genetic variation in four U. bullata populations on B. tectorum in the Intermountain region, with the objective of increasing basic understanding of this pathosystem as a prelude to possible use of $U$. bullata as a biocontrol agent for B. tectorum. We examined variation in pathogen virulence for each pathogen population on a series of inbreeding lines selected from the four cooccurring host populations. We studied patterns of variation in molecular markers (amplified fragment length polymorphisms [AFLPs]) among and within pathogen populations. We also examined the degree to which pathogen race identity and AFLP genotype were associated in the different pathogen populations and made inferences about inbreeding levels from these associations. Our investigations were designed to address the following hypotheses: (1) patterns of host resistance and pathogen virulence in cross-inoculation experiments will be consistent with a gene-for-gene model of host-pathogen interaction (Flor 1971); (2) neutral molecular markers and avirulence loci will show patterns of association that indicate high levels of inbreeding in the pathogen; (3) patterns of genetic differentiation for the pathogen populations will parallel those previously described for their co-occurring host populations, supporting the hypothesis that pathogen spore dispersal occurs primarily as seedborne inoculum.

\section{Material and Methods}

The four Bromus tectorum populations chosen for this study have been the subject of intensive ecological investigation for over a decade (table 1; Meyer et al. 1997, 2004; Meyer and Allen 1999). Host parental lines used in this ex- periment were first collected as the seed progeny of individual plants in 1992 as part of these earlier studies (Meyer and Allen 1999). Because the full-sib offspring of single highly homozygous host individuals are essentially genetically identical, seed increase through as many generations as necessary permitted the production of ample seeds of each parental line for experimental use.

In the summer of 1998 , bulk teliospore collections of the co-occurring Ustilago bullata population at each location were made by harvesting mature smutted B. tectorum panicles of at least 100 randomly selected individuals. These bulk collections were used in inoculation trials with seed progeny of six parental lines from each of the co-occurring host populations (Meyer et al. 2001). Pathogen isolates for use in this study were obtained from selected host lines included in these previously reported bulk inoculation trials. We chose this source for isolates rather than isolating from the original bulk inoculum so that we could more easily compare results from the two experiments.

\section{Cross-Inoculation Experiments}

Thirteen host parental lines for the cross-inoculation experiments were selected from the original set of 24 lines included in the bulk inoculation trials on the basis of their microsatellite marker genotypes (table 2; Ramakrishnan et al. 2004). Our aim was to reduce the size of our experiments by using only a single host line for each known microsatellite genotype included in the original bulk inoculation experiment. Because of space constraints, the cross-inoculation experiments with the four pathogen populations were carried out sequentially over a period of $2 \mathrm{yr}$. The subset of lines used in the experiment with each pathogen population varied depending on our state of knowledge of microsatellite genotypes at the initiation of each experiment.

For each host line included in a cross-inoculation experiment with a given pathogen population, monosporidial isolates were obtained from a bulked teliospore collection harvested from all individuals of that host line included in the bulk inoculation trial, i.e., up to 36 plants. Teliospores were atomized onto a PDAA (potato dextrose agar plus antibiotics) surface in petri dishes. After spore germination and some sporidial proliferation, sporidia were collected aseptically, dispersed, and diluted in sterile water, then plated on water agar plates. Apparent single sporidia were marked microscopically and left to form colonies large enough to be

Table 1

Location and Habitat Information for the Four Co-Occurring Host-Pathogen Populations Used in the Study

\begin{tabular}{|c|c|c|c|c|c|c|}
\hline \multirow[b]{2}{*}{ Population } & \multirow[b]{2}{*}{ Elevation $(\mathrm{m})$} & \multirow[b]{2}{*}{$\begin{array}{l}\text { Plant community } \\
\text { type }\end{array}$} & \multicolumn{3}{|c|}{ Climate information } & \multirow[b]{2}{*}{ County, state } \\
\hline & & & $\begin{array}{c}\text { Mean annual } \\
\text { precipitation }(\mathrm{mm})\end{array}$ & $\begin{array}{l}\text { Mean January } \\
\text { temperature }\left({ }^{\circ} \mathrm{C}\right)\end{array}$ & $\begin{array}{c}\text { Mean July } \\
\text { temperature }\left({ }^{\circ} \mathrm{C}\right)\end{array}$ & \\
\hline Whiterocks & 1450 & $\begin{array}{l}\text { Shadscale (cold } \\
\text { desert) }\end{array}$ & 180 & -2.3 & 25.8 & Tooele, Utah \\
\hline Hobble Creek & 1530 & $\begin{array}{l}\text { Big sagebrush/ } \\
\text { Gambel oak }\end{array}$ & 400 & -2.1 & 24.8 & Utah, Utah \\
\hline Strawberry & 2400 & Subalpine meadow & 560 & -7.8 & 16.1 & Wasatch, Utah \\
\hline Potosi Pass & 1500 & $\begin{array}{l}\text { Blackbrush (warm } \\
\text { desert margin) }\end{array}$ & 250 & 1.7 & 26.5 & Clark, Nevada \\
\hline
\end{tabular}


Table 2

Host Parental Lines Used in the Study, Their Microsatellite Genotypes, and the Frequency of Those Genotypes in Each of Four Host Populations in 1998 (from Ramakrishnan 2002)

\begin{tabular}{|c|c|c|c|c|c|c|c|c|c|c|}
\hline \multirow[b]{3}{*}{ Host line } & \multirow[b]{3}{*}{ Genotype } & \multirow[b]{3}{*}{ Origin } & \multicolumn{8}{|c|}{ Genotype frequency } \\
\hline & & & \multicolumn{2}{|c|}{ Whiterocks } & \multicolumn{2}{|c|}{ Hobble Creek } & \multicolumn{2}{|c|}{ Strawberry } & \multicolumn{2}{|c|}{ Potosi Pass } \\
\hline & & & $\mathrm{a}$ & $\mathrm{b}$ & a & $\mathrm{b}$ & $\mathrm{a}$ & $\mathrm{b}$ & a & $\mathrm{b}$ \\
\hline $15-1$ & CFBBBF & Whiterocks & 0 & 0 & 0 & 0 & 0 & 0 & 0 & 0 \\
\hline $15-4$ & DEBBDA & Whiterocks & 0 & 0 & 0 & 0 & 0 & 0 & 0 & 0 \\
\hline $15-7$ & DCBEDF & Whiterocks & 0 & 0.05 & 0 & 0 & 0 & 0 & 0 & 0 \\
\hline $15-8$ & IEBBBF & Whiterocks & 0.21 & 0 & 0 & 0 & 0 & 0 & 0.23 & 0.03 \\
\hline $15-10$ & CCBBDF & Whiterocks & 0 & 0 & 0 & 0 & 0 & 0 & 0 & 0 \\
\hline $18-2$ & GCBBDA & Hobble Creek & 0 & 0 & 0.20 & 0.31 & 0 & 0.06 & 0 & 0 \\
\hline $18-3$ & GCBBDA & Hobble Creek & 0 & 0 & 0.20 & 0.31 & 0 & 0.06 & 0 & 0 \\
\hline $18-4$ & DCBBBF & Hobble Creek & 0.06 & 0 & 0.20 & 0.04 & 0 & 0 & 0 & 0 \\
\hline $18-5$ & DCBBBF & Hobble Creek & 0.06 & 0 & 0.20 & 0.04 & 0 & 0 & 0 & 0 \\
\hline $28-1$ & KCCBDA & Strawberry & 0 & 0 & 0 & 0 & 0.44 & 0 & 0 & 0 \\
\hline $28-4$ & KCCBDA & Strawberry & 0 & 0 & 0 & 0 & 0.44 & 0 & 0 & 0 \\
\hline $28-6$ & DCBBDA & Strawberry & 0.32 & 0.40 & 0.13 & 0.08 & 0.28 & 0.19 & 0 & 0 \\
\hline \multirow[t]{2}{*}{$20-1$} & FEDDAE & Potosi Pass & 0 & 0 & 0 & 0 & 0 & 0 & 0.77 & 0.97 \\
\hline & & & 0.59 & 0.45 & 0.53 & 0.43 & 0.72 & 0.25 & 1.00 & 1.00 \\
\hline
\end{tabular}

Note. Each population is represented by two subpopulations. The original parental line collections (made in 1992) were from subpopulation "a" in each case. The last line shows the proportion of plants in each subpopulation that had genotypes represented in this study.

visible using a tetrad microscope. Colonies were then transferred to PD broth culture in flasks on an orbital shaker. Putative monosporidial cultures were then mixed on PDA in all combinations and observed for dikaryon formation.

For each pathogen population, isolates of complementary mating type from each host line were chosen for the crossinoculation trial. Mating plus and minus strains were increased in broth culture to produce monosporidial inoculant. These paired isolates were then inoculated onto seeds of each of the host lines prior to planting for a total of from 81 to 144 host line $\times$ pathogen isolate pair combinations, depending on the number of host lines in the test. Thirty-six inoculated seeds were planted for each host line $\times$ paired pathogen isolate combination, except for Potosi Pass, for which 24 seeds were planted per combination.

All inoculation trials were carried out under greenhouse conditions following the protocol described in Meyer et al. (2001). Inoculated seeds were planted in individual cells in root trainer boxes (Spencer-Lemaire, Edmonton, Canada), seedlings were allowed to establish for $3 \mathrm{wk}$, plants were vernalized and grown to flowering, and individuals were scored as smutted or unsmutted.

The six Potosi Pass host lines in the bulk inoculation trials were completely resistant to every pathogen race in the bulk inoculum from Whiterocks, Hobble Creek, and Strawberry (Meyer et al. 2001). Potosi Pass host lines were therefore not included in the cross-inoculation experiments with these northern pathogen populations, because isolates could not be obtained from the Potosi Pass lines. The cross-inoculation trials for the Potosi Pass pathogen population were also complicated by an unforeseen difficulty. We were able to isolate Potosi Pass sporidial cultures of both mating types from only six of the 11 host line bulk teliospore collections. For the other five teliospore collections, all the sporidial isolates obtained were of a single mating type, and cross-inoculation us- ing paired sporidial inocula was not possible. Patterns of resistance and virulence in the pathogenicity matrices resulting from the cross-inoculation experiments were used to deduce the probable existence and distribution of resistance genes in the host and avirulence genes in the pathogen.

\section{AFLP Marker Characterization and Analysis}

We chose AFLPs over other molecular marker systems used for fungi, e.g., isozymes (Bradford et al. 1975; Kirby 1987; Hellman and Christ 1991), RFLPs (McDonald et al. 1999), and microsatellites (Delmotte et al. 1999), because their greater variability combined with ease of development make them useful for population-level screening studies. A set of 12 sporidial isolates from each pathogen population was selected for AFLP marker characterization. Most of these isolates were chosen from those used in the cross-inoculation trials, but we were unable to include any of the original Hobble Creek isolates because of problems with culture contamination. Samples for DNA extraction were stored at $-80^{\circ} \mathrm{C}$ in a PDA-glycerin mixture. Following thawing, $4 \mathrm{~mL}$ of suspended culture were centrifuged, and pelleted cultures were then ground with liquid nitrogen and subjected to DNA extraction with the Dneasy Plant Mini Kit (Qiagen, Valencia, CA).

We performed all steps of the AFLP analysis essentially according to Vos et al. (1995), with minor variations as follows. Following restriction endonuclease digestion, samples were incubated for $15 \mathrm{~min}$ at $70^{\circ} \mathrm{C}$. A final concentration of $10 \mathrm{mM}$ radioactively labeled ATP was used in the ligation reaction, which was carried out at $22^{\circ} \mathrm{C}$ overnight. The ligation product was diluted 1 : 30 with TE $(10 \mathrm{mM}$ Tris- $\mathrm{HCl}$, $0.1 \mathrm{mM}$ EDTA, pH 8.0). No preamplification reaction was employed. Selective amplification was performed according to Vos et al. (1995) using the following primer combinations (lowercase "e" and "m" identify EcoRI and MseI primers, 
respectively; capital letters following identifier indicate selective base extensions): eAmA, eAmC, eAmG, eAmT, eCmA, eCmC, eCmG, eCmT, eGmA, eGmC, eGmG, eGmT, eTmA, eTmG, eTmT.

Samples were electrophoresed on a $5 \%$ denaturing polyacrylamide gel, which was then pressed onto blotting paper and dried. Kodak Imaging Screen K (Bio-Rad, Hercules, CA) was exposed to the dried gel for 6-12 h and visualized with the Molecular Imager FX (Bio-Rad). We analyzed these images to determine the presence of positive versus negative genotypes (presence or absence of bands) at each locus using the AFLP-Quantar 1.0 (Key Gene, Netherlands) analysis system.

The 15 AFLP primer combinations yielded 1100 total bands of which $156(14.2 \%)$ were polymorphic. We analyzed data for these 156 loci by first calculating a pairwise similarity matrix for the 48 isolates based on Dice's coefficient of similarity (Nei and Li 1979). In order to visualize the degree of similarity among the isolates, we used this matrix as input for principal coordinates analysis (PCoA; Quinn and Keough 2002). Isolates were plotted according to their scores on the first two coordinates from this analysis.

We also performed PCoA at the population level, using a pairwise similarity matrix with euclidean distance as the similarity measure (Quinn and Keough 2002). This analysis used population-level frequencies of the positive genotype at each of the AFLP loci as variables. We repeated this analysis with two subpopulations of the Potosi Pass pathogen population included as separate entities. We used correlation analysis to relate genetic distances among pathogen populations as revealed by PCo1 to genetic distances among corresponding host populations as measured by scores on the first axis from nonmetric multidimensional scaling analysis on host population microsatellite allele frequencies estimated from samples of 50 individuals per population in 1998 (Ramakrishnan 2002).

To quantify the degree of molecular genetic diversity within each pathogen population, we used two measures. The first was the percentage of polymorphic AFLP bands present in each population and, in Potosi Pass, subpopulation. The second measure was gene diversity (GD) as defined by Nei $\left(1987\right.$; GD $=\left[1-\Sigma p_{i}^{2}\right][n / n-1]$, where $p$ is the frequency of the $i$ th allele in the population and $n$ is the sample number). We averaged the GD values for each locus to obtain average gene diversity for each population and subpopulation. A mean GD value of 0 indicates allelic fixation at all measured loci.

\section{Results}

\section{Cross-Inoculation Experiments}

Cross-inoculation of 12 host lines with isolates from the Whiterocks pathogen population resulted in high infection levels for all 12 isolate pairs in 10 of the 12 host lines (fig. 1 ). Two of the host lines, $18-2$ and 18-3 from the Hobble Creek population, showed zero infection in response to inoculation with three of the isolate pairs, indicating the existence of a resistance allele in these host lines with a corresponding avirulence allele in the pathogen. Both of the resistant
Hobble Creek host lines belonged to the same microsatellite genotype (table 2). Infection levels in host-pathogen combinations in which the host line was susceptible were usually more than $90 \%$, but occasionally infection percentages as low as $61 \%$ were observed. Host lines with these levels of infection were scored as susceptible.

When nine host lines were cross-inoculated with isolates from the Strawberry pathogen population, a similar pattern emerged (fig. 2). Eight of nine host lines were susceptible to all nine Strawberry isolate pairs, although sometimes infection levels were relatively low, as low as $31 \%$ in one host line-isolate combination. There was no clear pattern to these intermediate infection percentages, which are provisionally considered indicative of susceptibility. The ninth host line was completely resistant to three of the nine pathogen isolate pairs. Once again, Hobble Creek host line 18-2 was the line demonstrating clear resistance. Because Hobble Creek 18-2 was resistant to isolates from both the Whiterocks and Strawberry pathogen populations, we infer that isolates from these two populations may share an avirulence allele. Hobble Creek host line 18-3 was not included in this experiment, so it is not known whether it would have been resistant to the Strawberry isolates.

When 12 host lines were cross-inoculated with pathogen isolates from the Hobble Creek population, only host lines from the Strawberry population showed a clear pattern of resistance (fig. 3). All three Strawberry host lines (28-1, 28-4, and 28-6) showed resistance to three of the isolate pairs (HC1510, HC184, and HC185), with infection percentages of $<10 \%$. Strawberry host lines $28-4$ and 28-6 also showed clear resistance to the HC182 isolate pair, while host line $28-1$ was marginally susceptible (31\% infection). In addition, host line 28-1 showed low infection percentages in response to two additional isolate pairs (HC151 with 19\% infection; HC157 with $6 \%$ infection). Once again, infection percentages in most of the remaining host-pathogen combinations were high. While these results are not as clear as those for the Whiterocks and Strawberry pathogen populations, the results imply the existence of resistance alleles at two additional loci, one shared by all three Strawberry host lines and one confined to 28-1. Microsatellite genotypes for 28-1 and 28-4 are identical (table 2), showing that individuals with the same molecular marker genotype do not always share identical resistance phenotypes.

Patterns of infection for the Potosi Pass isolate pairs from the six teliospore collections that yielded two mating types were essentially identical (fig. 4). All host lines from the three northern host populations were susceptible to these six isolate pairs, while the Potosi Pass host line 20-1 was completely resistant. This clearly demonstrates resistance polymorphism within this host population, with corresponding virulence polymorphism in the co-occurring pathogen population, since the isolates that could not infect the Potosi Pass 20-1 host genotype must have come from a different Potosi Pass host line, one not included in the experiment. Potosi Pass 20-1 is susceptible to the Potosi Pass pathogen race that infected it in the bulk inoculation trials, but it is resistant to the co-occurring pathogen race that infected six northern host lines in this trial. The sporidial isolates from host line 20-1 were among the five that showed complete mating type 


\begin{tabular}{|l|c|c|c|c|c|c|c|c|c|c|c|c|}
\hline $\begin{array}{c}\text { Host } \\
\text { line }\end{array}$ & \multicolumn{10}{|c|}{ Paired monosporidial isolates from the Whiterocks pathogen population } \\
\hline & 151 & 154 & 157 & 158 & 1510 & 182 & 183 & 184 & 185 & 281 & 284 & 286 \\
\hline $15-1$ & 81 & 97 & 97 & 97 & 100 & 100 & 100 & 100 & 61 & 100 & 100 & 100 \\
\hline $15-4$ & 100 & 100 & 91 & 100 & 94 & 97 & 100 & 100 & 100 & 97 & 100 & 100 \\
\hline $15-7$ & 100 & 100 & 97 & 100 & 100 & 100 & 100 & 100 & 74 & 100 & 100 & 100 \\
\hline $15-8$ & 100 & 100 & 97 & 100 & 100 & 89 & 97 & 100 & 92 & 100 & 100 & 97 \\
\hline $15-10$ & 89 & 91 & 91 & 64 & 91 & 97 & 91 & 100 & 100 & 100 & 100 & 100 \\
\hline $18-2$ & $\mathbf{0}$ & 97 & $\mathbf{0}$ & 100 & 88 & 100 & 100 & 97 & 97 & 97 & $\mathbf{0}$ & 97 \\
\hline $18-3$ & $\mathbf{0}$ & 91 & $\mathbf{0}$ & 97 & 61 & 100 & 92 & 100 & 97 & 94 & $\mathbf{0}$ & 97 \\
\hline $18-4$ & 100 & 97 & 86 & 100 & 89 & 97 & 100 & 97 & 94 & 100 & 100 & 100 \\
\hline $18-5$ & 100 & 94 & 85 & 92 & 87 & 92 & 97 & 94 & 97 & 86 & 77 & 97 \\
\hline $28-1$ & 77 & 91 & 91 & 91 & 100 & 82 & 100 & 100 & 89 & 100 & 100 & 100 \\
\hline $28-4$ & 86 & 89 & 100 & 97 & 94 & 94 & 74 & 93 & 83 & 89 & 100 & 88 \\
\hline $28-6$ & 100 & 83 & 78 & 86 & 81 & 89 & 100 & 100 & 100 & 100 & 100 & 100 \\
\hline
\end{tabular}

Fig. 1 Pathogenicity matrix from a cross-inoculation experiment with paired monosporidial isolates from 12 host lines belonging to three populations following bulk inoculation with teliospores from the Whiterocks pathogen population. Reported values represent disease incidence, i.e., percentage of flowering individuals that exhibited head smut disease. Shaded cells represent combinations where Whiterocks isolates were reinoculated onto the host line of origin. Numbers in bold indicate presence of a putative host resistance/pathogen avirulence locus combination. (Whiterocks host lines are numbers beginning with 15 , Hobble Creek host lines are numbers beginning with 18 , and Strawberry host lines are numbers beginning with 28.)

bias and could not be included in the cross-inoculation experiment.

We found evidence for four putative resistance loci in the host and complementary avirulence loci in the pathogen (table 3). Of these four resistance loci, only one, the resistance allele found in the Potosi Pass 20-1 genotype, was demonstrated to confer resistance to a race in the co-occurring pathogen population. Alleles at the other three loci conferred resistance to pathogen races not known from the co-occurring host population.

While most host line-pathogen isolate combinations gave infection percentages that were clearly indicative of susceptibility or resistance in the host, there were a sizeable number of cross-inoculations that gave intermediate infection percentages $(30 \%-80 \%$; figs. $1-4)$. These intermediate percentages tended to be more characteristic of certain host lines, particularly those from the Strawberry population, which showed intermediate percentages in one-quarter to one-half of the cross-inoculations scored as susceptible, as opposed to less than a tenth of the cross-inoculations for the Whiterocks and Hobble Creek host lines. Intermediate percentages were also more common in the cross-inoculation trial with the Strawberry pathogen population (fig. 2). A host-by-pathogen population interaction is evident in the Potosi Pass trial, where the only susceptible lines to show infection percentages of $<95 \%$ belonged to the Strawberry host population.

\section{AFLP Marker Analysis}

The Potosi Pass pathogen population showed much less genetic diversity overall in terms of AFLP markers than the northern pathogen populations in the study, with only $49 \%$ polymorphic bands. The northern populations had $89 \%-$ 96\% polymorphic bands and also had higher average gene diversity $(0.395-0.419)$ than the Potosi Pass population (0.226).

PCoA based on AFLP markers for individual isolates from the four pathogen populations revealed a very interesting pattern (fig. 5A). Isolates from each of the northern populations are arrayed in a loose scatter with few clear groupings within populations and with broad areas of overlap among populations, a reflection of high among-isolate variation and the weak differentiation among populations for the northern group.

In contrast, the Potosi Pass isolates are arrayed in two tight groups that show no overlap with other populations and that are distant from each other, in spite of sharing the same AFLP genotype at almost half of the marker loci (fig. 5A). Isolates within each of these Potosi Pass subpopulations have identical AFLP genotypes at $85 \%-90 \%$ of the marker loci, resulting in very low genetic diversity values (0.060-0.070). In addition, members of the two subpopulations are fixed for different alleles at almost $30 \%$ of the total AFLP markers. All the included isolates from host lines that yielded two mating types and were avirulent on line 20-1 are in the larger 


\begin{tabular}{|c|c|c|c|c|c|c|c|c|c|c|c|c|}
\hline $\begin{array}{c}\text { Host } \\
\text { line }\end{array}$ & \multicolumn{7}{|c|}{ Paired monosporidial isolates from the Strawberry pathogen population } \\
\hline & 151 & 154 & 157 & 158 & 1510 & 182 & 183 & 184 & 185 & 281 & 284 & 286 \\
\hline $15-1$ & 91 & 97 & -- & 31 & 97 & 94 & -- & 97 & 44 & 86 & 76 & -- \\
\hline $15-4$ & 94 & 97 & -- & 58 & 91 & 97 & -- & 100 & 78 & 97 & 97 & -- \\
\hline $15-7$ & -- & -- & -- & -- & -- & -- & -- & -- & -- & -- & -- & -- \\
\hline $15-8$ & 90 & 100 & -- & 94 & 94 & 94 & -- & 100 & 92 & 97 & 88 & - \\
\hline $15-10$ & 94 & 100 & -- & 69 & 97 & 78 & -- & 97 & 43 & 91 & 78 & -- \\
\hline $18-2$ & 100 & $\mathbf{0}$ & -- & 89 & $\mathbf{0}$ & 86 & -- & 100 & $\mathbf{0}$ & 89 & 89 & -- \\
\hline $18-3$ & -- & -- & -- & -- & -- & -- & -- & -- & -- & - & - & -- \\
\hline $18-4$ & 100 & 86 & -- & 86 & 97 & 72 & -- & 100 & 92 & 91 & 43 & - \\
\hline $18-5$ & 86 & 91 & -- & 72 & 82 & 89 & -- & 100 & 92 & 97 & 97 & -- \\
\hline $28-1$ & 85 & 75 & -- & 77 & 76 & 91 & -- & 100 & 83 & 75 & 74 & -- \\
\hline $28-4$ & 74 & 75 & -- & 94 & 72 & 97 & -- & 97 & 94 & 82 & 97 & - \\
\hline $28-6$ & -- & -- & -- & -- & -- & -- & -- & -- & -- & -- & -- & -- \\
\hline
\end{tabular}

Fig. 2 Pathogenicity matrix from a cross-inoculation experiment with paired monosporidial isolates from nine host lines belonging to three populations following bulk inoculation with teliospores from the Strawberry pathogen population. Reported values represent disease incidence, i.e., percentage of flowering individuals that exhibited head smut disease. Shaded cells represent combinations where Strawberry isolates were reinoculated onto the host line of origin. Numbers in bold indicate presence of a putative host resistance/pathogen avirulence locus combination. Dashed lines indicate host line and pathogen isolate not included in experiment. (Whiterocks host lines are numbers beginning with 15, Hobble Creek host lines are numbers beginning with 18, and Strawberry host lines are numbers beginning with 28.)

subpopulation, while all those isolates from host lines, including line 20-1, that yielded only a single mating type are in the smaller subpopulation. The northern host lines whose isolates showed complete mating type bias were most likely infected with the same pathogen race that is virulent on $\mathrm{Po}^{-}$ tosi Pass host line 20-1. Otherwise it would be difficult to understand how these isolates, which would be obligately inbreeding and reproductively isolated from other pathogen races, could be so nearly identical to the race virulent on 20-1 in terms of AFLP genotype. This indicates that the two Potosi Pass subpopulations correspond to phenotypes that lack mating type bias and are avirulent on host line 20-1 and phenotypes that possess mating type bias and are probably all virulent on host line 20-1.

In contrast to isolates from Potosi Pass, isolates from northern pathogen populations belonging to the subset that exhibited avirulence on the Hobble Creek 18-2 host line show no pattern of association with AFLP genotype. For example, a proportion of shared AFLP bands for four Whiterocks isolates that were included in crosses exhibiting the presence of putative $\mathrm{avr}_{2}$ (table 3) ranged from 0.47 to 0.70 . The average number of shared bands for all Whiterocks isolates combined was 0.65 , showing that the isolates likely to share an avirulence allele were no more similar than average. Similarly, four Strawberry isolates that possessed putative $\mathrm{avr}_{2}$ shared from 0.58 to 0.66 AFLP bands, similar to the average value $(0.65)$ for the Strawberry population. The Strawberry and Whiterocks avr 2 isolates shared from 0.46 to
0.65 bands. This lack of association between putative $\mathrm{avr}_{2}$ and AFLP genotype is evidence for outcrossing in the Whiterocks and Strawberry pathogen populations.

Only 14 pairwise comparisons out of a total of 198 for all the northern pathogen isolates gave shared AFLP band values $>0.80$, and all of these were between isolates within populations. Nine of the high pairwise values involved a group of five Hobble Creek isolates, while another three involved a group of three Strawberry isolates. Only one of 66 Whiterocks pairwise comparisons gave a value $>0.80$. The general failure of isolates to form groups of closely similar individuals is further evidence for outbreeding in the northern pathogen populations, though this evidence is not conclusive because of the relatively small number of isolates examined.

When we performed PCoA using AFLP frequencies at the population level, the Strawberry and Hobble Creek populations were shown to be closely similar, while the Whiterocks and Potosi Pass populations were more distant both from the Strawberry-Hobble Creek pair and from each other (fig. 5B). This analysis is somewhat misleading because it uses average frequencies for the Potosi Pass population, making it appear more similar to the northern populations, when in fact this population is effectively divided into two subpopulations that apparently rarely, if ever, interbreed. When AFLP frequencies for the two subpopulations are included separately, it becomes clear that the two subpopulations are as different from each other as they are from the northern populations, 


\begin{tabular}{|c|c|c|c|c|c|c|c|c|c|c|c|c|}
\hline $\begin{array}{c}\text { Host } \\
\text { line }\end{array}$ & \multicolumn{10}{|c|}{ Paired monosporidial isolates from the Hobble Creek pathogen population } \\
\hline & 151 & 154 & 157 & 158 & 1510 & 182 & 183 & 184 & 185 & 281 & 284 & 286 \\
\hline $15-1$ & 100 & 97 & 100 & 100 & 100 & 97 & 94 & 91 & 100 & 100 & 71 & 97 \\
\hline $15-4$ & 100 & 97 & 97 & 100 & 100 & 97 & 94 & 100 & 97 & 100 & 84 & 88 \\
\hline $15-7$ & 100 & 100 & 100 & 100 & 100 & 97 & 100 & 97 & 100 & 100 & 95 & 100 \\
\hline $15-8$ & 94 & 100 & 100 & 100 & 100 & 100 & 63 & 97 & 100 & 100 & 100 & 100 \\
\hline $15-10$ & 100 & 100 & 92 & 100 & 100 & 97 & 100 & 94 & 97 & 100 & 67 & 58 \\
\hline $18-2$ & 100 & 94 & 91 & 100 & 100 & 100 & 100 & 97 & 100 & 100 & 86 & 89 \\
\hline $18-3$ & 94 & 100 & 100 & 100 & 100 & 97 & 89 & 92 & 100 & 97 & 94 & 97 \\
\hline $18-4$ & 92 & 82 & 92 & 100 & 100 & 100 & 97 & 100 & 97 & 100 & 89 & 94 \\
\hline $18-5$ & 100 & 100 & 94 & 100 & 100 & 92 & 94 & 97 & 100 & 100 & 33 & 100 \\
\hline $28-1$ & 19 & 88 & $\mathbf{6}$ & 100 & $\mathbf{7}$ & 31 & 42 & $\mathbf{3}$ & $\mathbf{0}$ & 100 & 94 & 74 \\
\hline $28-4$ & 88 & 81 & 92 & 68 & $\mathbf{0}$ & $\mathbf{3}$ & 56 & $\mathbf{0}$ & $\mathbf{0}$ & 100 & 97 & 86 \\
\hline $28-6$ & 91 & 75 & 97 & 69 & $\mathbf{6}$ & $\mathbf{0}$ & 40 & $\mathbf{0}$ & $\mathbf{9}$ & 100 & 89 & 97 \\
\hline
\end{tabular}

Fig. 3 Pathogenicity matrix from a cross-inoculation experiment with paired monosporidial isolates from 12 host lines belonging to three populations following bulk inoculation with teliospores from the Hobble Creek pathogen population. Reported values represent disease incidence, i.e., percentage of flowering individuals that exhibited head smut disease. Shaded cells represent combinations where Hobble Creek isolates were reinoculated onto the host line of origin. Numbers in bold indicate presence of a putative host resistance/pathogen avirulence locus combination. (Whiterocks host lines are numbers beginning with 15, Hobble Creek host lines are numbers beginning with 18, and Strawberry host lines are numbers beginning with 28.)

which are in turn very similar to each other by comparison (fig. 5C).

\section{Discussion}

We found clear evidence for variation in pathogen virulence and corresponding host resistance in the Bromus tectorumUstilago bullata pathosystem. The distinction between hostpathogen combinations exhibiting resistance or susceptibility was generally sharp, indicating that these traits may be governed in accordance with the gene-for-gene model of racespecific resistance, as is reported for other Ustilago species (e.g., Holton and Halisky 1960 for Ustilago avenae). We present evidence for the existence of four avirulence loci in the pathogen and corresponding resistance loci in the host (table 3). Further experiments will be required to confirm that these traits are controlled by single genes.

The pattern of intermediate infection percentages for some host lines implies that there may also be a horizontal resistance element operating in these lines, which do not appear to have race-specific resistance alleles against specific pathogen isolates but which nonetheless show generally lower levels of infection than other susceptible host lines in cross-inoculations with a range of different isolates. The lower levels of infection for susceptible lines overall with Strawberry as compared with Whiterocks and Hobble Creek isolates could result from variation in genes that affect the incidence or expression of disease in otherwise susceptible hosts, i.e., genes that govern quantitative "aggressiveness" traits, as found in Ustilago bordei (Pope and Wehrhahn 1991). Alternatively, since these trials were not carried out contemporaneously, some unquantified difference in environmental conditions may have caused lower infection overall in the Strawberry trial.

Most of the northern pathogen isolates were virulent on all the host lines included in the trials, whether from the same or different populations, and none was avirulent on host lines from the co-occurring host population. This raises the question of the function of corresponding resistance genes in the host. Because of our small sample sizes, we have not fully examined the possibility that resistance genes against cooccurring pathogen races exist in the northern host populations, and we found a clear example of such a resistance gene in the Potosi Pass host population. But the idea of within-population resistance polymorphism maintained by frequency-dependent selection (Frank 1993; Chaboudez and Burdon 1995) is not supported by our data.

Burdon et al. (1996) noted that the pattern we observed, namely resistance to pathogen races that are not co-occurring, is more the norm than the exception in natural pathosystems. They proposed that the function of this resistance is to slow the rate of reinvasion by the pathogen following local extinction events and hypothesized that it would be more common in pathosystems where such local pathogen extinction is probable. Bromus tectorum occurs in highly disturbed ecosystems where catastrophic stand loss is common. It survives 


\begin{tabular}{|l|c|c|c|c|c|c|c|c|c|c|c|c|c|}
\hline $\begin{array}{c}\text { Host } \\
\text { line }\end{array}$ & \multicolumn{7}{|c|}{ Paired monosporidial isolates from the Potosi Pass pathogen population } \\
\hline & $151^{\text {a }}$ & 154 & 157 & 158 & $1510^{\mathrm{a}}$ & 182 & $183^{\mathrm{a}}$ & $184^{\mathrm{a}}$ & 185 & 281 & 284 & 286 & $201^{\mathrm{a}}$ \\
\hline $15-1$ & yes & 100 & --- & 100 & $/$ & 97 & $/$ & $/$ & 100 & 96 & 100 & --- & $/$ \\
\hline $15-4$ & $/$ & 100 & --- & 100 & $/$ & 100 & $/$ & $/$ & 100 & 100 & 100 & --- & $/$ \\
\hline $15-7$ & --- & --- & --- & --- & --- & --- & --- & --- & --- & -- & -- & --- & -- \\
\hline $15-8$ & $/$ & 100 & --- & 100 & $/$ & 100 & $/$ & $/$ & 100 & 100 & 100 & --- & $/$ \\
\hline $15-10$ & $/$ & 100 & --- & 100 & yes & 100 & $/$ & $/$ & 96 & 100 & 100 & --- & $/$ \\
\hline $18-2$ & $/$ & 100 & --- & 100 & $/$ & 100 & $/$ & $/$ & 100 & 96 & 100 & --- & $/$ \\
\hline $18-3$ & $/$ & 100 & --- & 100 & $/$ & 100 & yes & $/$ & 100 & 100 & 96 & --- & $/$ \\
\hline $18-4$ & $/$ & 100 & --- & 100 & $/$ & 95 & $/$ & yes & 100 & 100 & 100 & --- & $/$ \\
\hline $18-5$ & $/$ & 100 & --- & 97 & $/$ & 100 & $/$ & $/$ & 100 & 100 & 100 & --- & $/$ \\
\hline $28-1$ & $/$ & 100 & --- & 86 & $/$ & 70 & $/$ & $/$ & 71 & 71 & 79 & --- & $/$ \\
\hline $28-4$ & $/$ & 83 & --- & 73 & $/$ & 81 & $/$ & $/$ & 82 & 70 & 48 & --- & $/$ \\
\hline $28-6$ & --- & --- & --- & --- & --- & --- & --- & --- & -- & -- & -- & --- & --- \\
\hline $20-1$ & $/$ & $\mathbf{0}$ & --- & $\mathbf{0}$ & $/$ & $\mathbf{0}$ & $/$ & $/$ & $\mathbf{0}$ & $\mathbf{0}$ & $\mathbf{0}$ & --- & yes \\
\hline
\end{tabular}

Fig. 4 Pathogenicity matrix from a cross-inoculation experiment with paired monosporidial isolates from six host lines belonging to three populations following bulk inoculation with teliospores from the Potosi Pass pathogen population. Reported values represent disease incidence, i.e., percentage of flowering individuals that exhibited head smut disease. Shaded cells represent combinations where Potosi Pass isolates were reinoculated onto the host line of origin. Numbers in bold indicate presence of a putative host resistance/pathogen avirulence locus combination. The isolate pair marked with a superscript "a" could infect the host line from which it was isolated; missing data for other host lines are shown with slashes. Dashed lines show host-pathogen combination not included. (Whiterocks host lines are numbers beginning with 15, Hobble Creek host lines are numbers beginning with 18, Potosi Pass host lines are numbers beginning with 20, and Strawberry host lines are numbers beginning with 28.)

such events, including drought, wildfire, and grasshopper herbivory, through seed bank persistence. We have field data indicating that $U$. bullata is likely to be driven to local extinction by these events; it does not appear to be capable of spore banking across years (S. E. Meyer and D. L. Nelson, unpublished data). It relies on reinvasion through airborne or seedborne inoculum, which is just the scenario envisioned by Burdon et al. (1996).
The patterns of molecular genetic variation we observed for $U$. bullata in this study support the hypothesis that the northern populations are not strongly differentiated and that the Potosi Pass population is genetically distinct from the northern populations. Genetic distance scores based on PCo1 from the pathogen AFLP analysis are also significantly correlated with analogous genetic distance scores for the corresponding host populations $(r=0.988, \mathrm{df}=2, P<0.002$; Ramakrishnan

Table 3

Putative Host Resistance Loci and Corresponding Pathogen Avirulence Loci, Based on Results of Cross-Inoculation Experiments Presented in Figures 1-4 and by Meyer et al. (2001), and Their Distribution among Populations and Lines

\begin{tabular}{|c|c|c|c|c|c|}
\hline $\begin{array}{l}\text { Resistance } \\
\text { locus }\end{array}$ & $\begin{array}{l}\text { Host } \\
\text { lines }\end{array}$ & $\begin{array}{c}\text { Host } \\
\text { populations }\end{array}$ & $\begin{array}{l}\text { Avirulence } \\
\text { locus }\end{array}$ & $\begin{array}{l}\text { Pathogen } \\
\text { lines }\end{array}$ & $\begin{array}{l}\text { Pathogen } \\
\text { populations }\end{array}$ \\
\hline $\mathrm{R}_{1}$ & $\begin{array}{l}20-1,20-2,20-3,20-4 \\
\quad 20-5,20-6\end{array}$ & Potosi Pass & $\operatorname{avr}_{1}$ & $\begin{array}{l}\text { All northern lines; } \\
\text { PP154, PP158, } \\
\text { PP182, PP185, } \\
\text { PP281, PP286 }\end{array}$ & $\begin{array}{l}\text { Whiterocks, Hobble Creek, } \\
\text { Strawberry, Potosi Pass }\end{array}$ \\
\hline $\mathrm{R}_{2}$ & $18-2,18-3$ & Hobble Creek & $\mathrm{avr}_{2}$ & $\begin{array}{l}\text { WR151, WR157, } \\
\text { WR284, ST154, } \\
\text { ST1510, ST185 }\end{array}$ & Whiterocks, Strawberry \\
\hline $\mathrm{R}_{3}$ & $28-1,28-4,28-6$ & Strawberry & $\operatorname{avr}_{3}$ & $\begin{array}{r}\mathrm{HC} 1510, \mathrm{HC} 182, \\
\text { HC184, HC185 }\end{array}$ & Hobble Creek \\
\hline $\mathrm{R}_{4}$ & $28-1$ & Strawberry & $\mathrm{avr}_{4}$ & HC151, HC153 & Hobble Creek \\
\hline
\end{tabular}



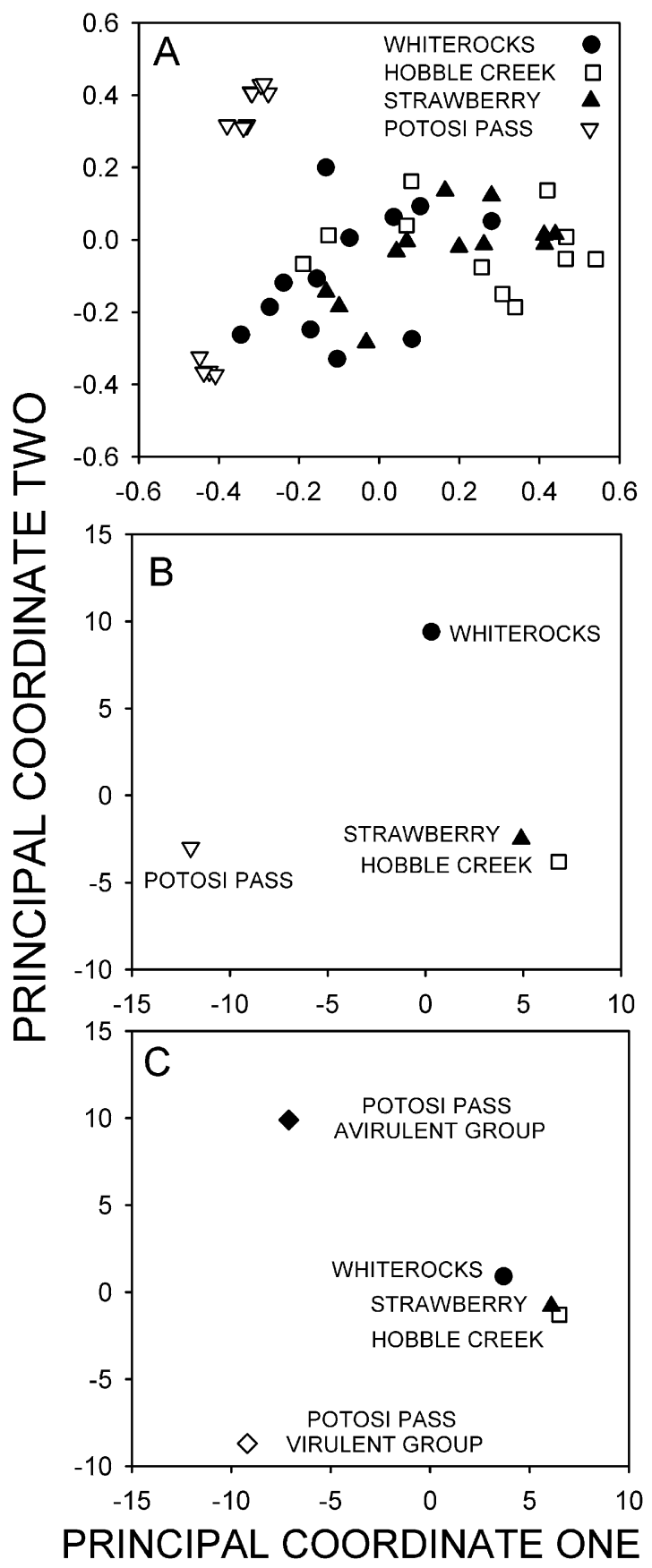

Fig. $5 A$, Twelve sporidial isolates from each of four pathogen populations plotted according to their scores on the first two principal coordinates (PCo's) from principal coordinates analysis (PCoA) of AFLP genotypes using Dice's coefficient of similarity. PCo- 1 accounted for $20.8 \%$ of the total variation while PCo- 2 accounted for $11.5 \%$. B, Four pathogen populations plotted according to their scores on the first two PCo's from PCoA of AFLP genotype frequencies using average taxonomic distance as the dissimilarity metric. PCo- 1 accounted for $50.2 \%$ of the variation while PCo- 2 accounted for $27.7 \%$. C, Three pathogen populations and two subpopulations of the Potosi Pass pathogen population plotted according to their scores on the first two PCo's from PCoA of AFLP genotype frequencies using average taxonomic distance as the dissimilarity metric. PCo- 1 accounted for $40.1 \%$ of the variation while PCo- 2 accounted for $31.2 \%$.
2002). The concordance of genetic distances between host and pathogen populations implies that host and pathogen may have similar patterns of migration and gene flow among populations in spite of generally contrasting breeding systems. These genetic distances are in turn correlated with geographic distance in that the Potosi Pass location is geographically distant from the three northern locations, which are in relatively close proximity (table 1 ). These results are consistent with the idea of seedborne transmission of pathogen inoculum (i.e., primary dispersal onto the seeds of adjacent uninfected host plants, followed by secondary dispersal along with these seeds) but do not conclusively demonstrate this mode of dispersal.

In this pathosystem, the pathogen is more genetically variable than the host. Bromus tectorum is highly inbreeding and showed considerably lower AFLP polymorphism (3\% polymorphic bands; Ramakrishnan et al. 2004) than U. bullata from co-occurring pathogen populations (14\% polymorphic bands). The AFLP data also support the hypothesis that the northern pathogen populations are outcrossing. This combination of an inbreeding host with an outcrossing pathogen would tend to give rise to a pathosystem where the pathogen can evolve more rapidly than the host. Combined with pathogen migration rates as high as or higher than those of the host, this may account for near-universal virulence on cooccurring host populations. In the Microbotrium (=Ustilago) violaceum-Silene latifolia pathosystem, in contrast, the host is an obligate outbreeder and has higher migration rates than the highly inbreeding pathogen (Delmotte et al. 1999). This has given rise to a system where the pathogen is locally maladapted, i.e., less virulent on co-occurring than on distant host populations (Kaltz et al. 1999).

Potosi Pass host line 20-1 represents the dominant microsatellite genotype at Potosi Pass (table 2). This genotype is associated with a resistance allele that renders it resistant to pathogen races present in field bulk teliospore collections from Whiterocks, Hobble Creek, and Strawberry, presumably because they possess a corresponding avirulence allele (Meyer et al. 2001). This avirulence allele appears to be present within the Potosi Pass pathogen population as well. A second host microsatellite genotype is present at Potosi Pass at low frequency (Ramakrishnan 2002). This second genotype is also present in the Whiterocks population and provides a susceptible host for the subpopulation of the pathogen at Potosi Pass that is avirulent on the prevalent genotype. More recent data show that the uncommon host microsatellite genotype at Potosi Pass is susceptible to both of the pathogen races found there (S. E. Meyer and D. L. Nelson, unpublished data). The avirulent pathogen race was apparently collected along with the race pathogenic on the prevalent host genotype in the original field bulk inoculum.

Some northern host lines in the Potosi Pass bulk inoculum test appear to have been infected only by the pathogen race associated with the mating type bias, as evidenced by the fact that all sporidia isolated from their teliospores were of a single mating type. But these same northern host lines were also susceptible to the other pathogen race present in the inoculum, as shown by their susceptibility to this race when it was applied as a sporidial isolate pair (fig. 4). A peculiarity of our data set is the fact that host lines susceptible to both races 
were apparently infected by only one or the other of the two races. In M. violaceum, competition among genetically contrasting dikaryons within host tissues can lead to a winner so that all the teliospores produced on a host plant are genetically identical (Baird and Garber 1979). This might explain how a host plant susceptible to two pathogen races in bulk inoculum could produce only teliospores of a single race.

Mating locus-linked haplolethal deficiency mutations, which prevent the survival of one of the mating types as freeliving sporidia, have been reported from several species of Ustilago, including U. bullata (Fischer 1940b; Holton and Dietz 1960). They have been best studied in M. violaceum, where they are a frequent occurrence in pathosystems involving caryophyllaceous host species on two continents (Kaltz and Shykoff 1997; Oudemans et al. 1998). This fungus infects via the host flower and is dispersed by insect vectors, and consequently is delivered directly to the infection court, where it must form a heterokaryon and penetrate quickly, before flower dehiscence. Under these conditions, there seems to be little advantage to sporidial proliferation, and intratetrad mating (i.e., mating between the products of a single meiosis) is a common feature of the breeding system (Hood and Antonovics 2000). Selfing allows the persistence of haplolethal mutations, because they are not exposed to selection in the haploid state and can thus be passed on to progeny. Ustilago bullata, on the other hand, is a seedling-infecting fungus whose primary dispersal is by wind and rain; the encounter with the infection court on an emerging coleoptile occurs largely by chance. Sporidial proliferation increases the probability of this encounter and should therefore be selected for in this pathosystem.

Detection of a mating locus-linked haplolethal mutation in the virulent race at Potosi Pass is good evidence for a high incidence of intratetrad selfing in this race. In addition, the fact that most AFLP markers are fixed implies that this race is highly inbreeding and reproductively isolated from the other pathogen race at Potosi Pass. The haplolethal mutation is maintained in the heterozygous condition by its linkage to the mating type locus. This prevents its expression in the dikaryotic stage. Intratetrad selfing preserves heterozygosity relative to other inbreeding systems because each gamete has limited mate choices (i.e., sampling occurs without replace- ment so that for a gene present in heterozygous condition, mating with a gamete that has the opposite allele is twice as likely as mating with a gamete that has the same allele; Kirby 1984). This may explain why a tenth of the AFLP markers are still polymorphic in this highly inbred race.

The strong genetic resemblance among the isolates of the Potosi Pass avirulent group is less easily explained. Bromus tectorum is a relative newcomer to the warm deserts of southern Nevada (Beatley 1966). The prevalent 20-1 host genotype at Potosi Pass possesses adaptive traits, such as high seed dormancy at summer temperatures and lack of a vernalization requirement for flowering, which make it uniquely suited to this warm desert environment (Meyer and Allen 1999; Meyer et al. 2004). It is only distantly related to northern $B$. tectorum lines, with unique alleles at five of six microsatellite loci (table 2). The other host line detected at Potosi Pass possesses none of these warm desert adaptations (S. E. Meyer and D. L. Nelson, personal observation) and may be at an adaptive disadvantage, as would any other northern host line that happened to be introduced there. The low diversity of the pathogen race that must survive by infecting this line could result from passage through a population genetic bottleneck ( $\mathrm{Nei}$ et al. 1975). At some point in the past, this poorly adapted host line could have experienced nearly complete reproductive failure, reducing the population of this pathogen race to very small size. This could account for its low genetic diversity, even though it continues to propagate via sporidial mating, with the potential for outcrossing that this implies.

\section{Acknowledgments}

We thank Alisa Ramakrishnan for help with the statistical analysis of the AFLP data and for many fruitful discussions of molecular genetics of both host and pathogen. Jacob Durrant developed the spreadsheet program for calculating shared band percentages. This research was supported in part by grants from the USDA Cooperative State Research, Extension, and Education Service National Research Initiative Competitive Grants Program: grant 98-35303-6957 from the Plant Pathology Program and grant 2000-35319-09920 from the Biology of Plant-Microbe Interactions Program.

\section{Literature Cited}

Baird ML, ED Garber 1979 Genetics of Ustilago violacea. V. Outcrossing and selfing in teliospore inocula. Bot Gaz 140:89-93.

Beatley JC 1966 Ecological status of introduced brome grasses (Bromus spp.) in the desert vegetation of southern Nevada. Ecology 47:548-554.

Bradford LS, RJ Jones, ED Garber 1975 An electrophoretic survey of fourteen species of the genus Ustilago. Bot Gaz 136:109-115.

Burdon JJ, A Wennstrom, T Elmqvist, GC Kirby 1996 The role of race-specific resistance in natural plant populations. Oikos 76: 411-416.

Chaboudez P, JJ Burdon 1995 Frequency-dependent selection in a wild plant-pathogen system. Oecologia 102:490-493.

Delmotte F, E Bucheli, JA Shykoff 1999 Host and parasite population structure in a natural plant-pathogen system. Heredity 82:300-308.

Fischer GW $1940 a$ Host specialization in the head smut of grasses, Ustilago bullata. Phytopathology 30:991-1017.
$1940 b$ Two cases of haplo-lethal deficiency in Ustilago bullata operative against saprophytism. Mycologia 32:275-289.

Fischer GW, CS Holton 1957 Biology and control of the smut fungi. Ronald, New York. 622 pp.

Flor HH 1971 Current status of the gene-for-gene concept. Annu Rev Phytopathol 7:275-296.

Frank SR 1993 Coevolutionary genetics of plants and pathogens. Evol Ecol 7:45-75.

Hellman R, BJ Christ 1991 Isozyme variation of physiologic races of Ustilago hordei. Phytopathology 81:1536-1540.

Holton CS, SM Dietz 1960 An apparent association between haploid lethal factors with two unique sorus types of oat smut. Phytopathology 50:749-751.

Holton CS, PM Halisky 1960 Dominance of avirulence and monogenic control of virulence in race hybrids of Ustilago avenae. Phytopathology 50:766-770. 
Hood ME, J Antonovics 2000 Intratetrad mating, heterozygosity, and the maintenance of deleterious alleles in Microbotryum violaceum. Heredity 85:231-241.

Kaltz O, S Gandon, Y Michalakis, JA Shykoff 1999 Local maladaptation in the anther-smut fungus Microbotryum violaceum to its host plant Silene latifolia: evidence from a cross-inoculation experiment. Evolution 53:395-407.

Kaltz O, JA Shykoff 1997 Sporidial mating-type ratios of teliospores from natural populations of the anther smut fungus Microbotryum (=Ustilago) violaceum. Int J Plant Sci 158:575-584.

Kirby GC 1984 Breeding systems and heterozygosity in populations of tetrad-forming fungi. Heredity 52:35-41.

1987 Variation in Ustilago bullata on Agropyron scabrum in Australia and New Zealand. Australas Plant Pathol 16:10-12.

Kreizinger EJ, GW Fischer, AG Law 1947 Reaction of mountain brome and Canada wildrye strains to head smut (Ustilago bullata). J Agric Res 75:105-111.

McDonald BA, J Zhan, JJ Burdon 1999 Genetic structure of Rhynchosporium secalis in Australia. Phytopathology 89:639645 .

McKone MK 1985 Reproductive biology of several bromegrasses (Bromus): breeding system, pattern of fruit maturation, and seed set. Am J Bot 72:1334-1339.

Meiners JP, GW Fischer 1953 Further studies on host specialization in the head smut of grasses, Ustilago bullata. Phytopathology 43: 200-203.

Meyer SE, PS Allen 1999 Ecological genetics of seed germination regulation in Bromus tectorum L. I. Phenotypic variance among and within populations. Oecologia 120:27-34.

Meyer SE, PS Allen, J Beckstead 1997 Seed germination regulation in Bromus tectorum (Poaceae) and its ecological significance. Oikos 78:475-485.

Meyer SE, DL Nelson, SL Carlson 2004 Ecological genetics of vernalization response in Bromus tectorum L. Ann Bot 93:653663.

Meyer SE, DL Nelson, S Clement 2001 Evidence for resistance polymorphism in the Bromus tectorum-Ustilago bullata pathosystem: implications for biocontrol. Can J Plant Pathol 23:19-27.
Nei M 1987 Molecular evolutionary genetics. Columbia University Press, New York.

Nei M, WH Li 1979 Mathematical model for studying genetic variation in terms of restriction endonucleases. Proc Natl Acad Sci USA 76:5269-5273.

Nei M, T Maruyama, R Chakraborty 1975 The bottleneck effect and genetic variability in populations. Evolution 29:1-10.

Novak SJ, RN Mack 2001 Tracing plant introduction and spread: genetic evidence from Bromus tectorum (cheatgrass). BioScience 51: 114-122.

Oudemans PV, HM Alexander, J Antonovics, S Alitzer, PH Thrall, L Rose 1998 The distribution of mating-type bias in natural populations of the anther-smut Ustilago violacea on Silene alba in Virginia. Mycologia 90:372-381.

Pope DD, CF Wehrhahn 1991 Quantitative genetics of disease incidence in Ustilago hordei controlled by virulence and aggressiveness genes. Can J Bot 69:420-427.

Quinn GP, SJ Keough 2002 Experimental design and data analysis for biologists. Cambridge University Press, New York.

Ramakrishnan AP 2002 Molecular marker variation in Intermountain West populations of Bromus tectorum. MS thesis. Brigham Young University, Provo, UT.

Ramakrishnan AP, SE Meyer, DJ Fairbanks, CE Coleman 2004 Correlation of molecular markers and adaptively significant traits in Bromus tectorum, an inbreeding annual grass. Am J Bot 91: 797-803.

Rice KJ, MN Mack 1991 Ecological genetics of Bromus tectorum L. I. A hierarchical analysis of phenotypic variation. Oecologia 88: $77-83$.

Vos P, R Hogers, M Bleeker, M Reijans, T Van de Lee, M Hornes, A Frijters, et al 1995 AFLP: a new technique for DNA fingerprinting. Nucleic Acids Res 23:4407-4414.

Whisenant SG 1990 Changing fire frequencies on Idaho's Snake River Plains: ecological and management implications. Pages 4-10 in ED McArthur, EM Romney, SD Smith, PT Tueller, eds. Proceedings from Symposium on Cheatgrass Invasion, Shrub DieOff, and Other Aspects of Shrub Biology and Management. USDA Forest Service General Technical Report INT-276, Ogden, UT. 